\title{
Perceptions of Principals and Teachers on the Level of Organizational Narcissism, High Schools in Sakarya Province Sample
}

\author{
Mehmet Ali HAMEDOĞLU*
}

\begin{abstract}
This research examining the level of organizational narcissism and its relations to some variables was completed by the help of data picked from 18 high schools in Sakarya province. Both private and public high schools including general high schools, science and Anatolian high schools have constituted the universe of this study. The sample, a total of 299 teaching stuff, were selected those specified high schools' including 46 managers and 253 teachers of 299 people formed the research sample. The results of the research showed that socioeconomic level and academic achievement linearly related to organizational narcissism. Because the level of organizational narcissism of private schools were higher than those of the public schools and the level of organizational narcissism of Anatolian and science high schools for which their teachers and students are selected via a national entrance and placement examination were higher than those of general high schools. For some reasons, such as having a perception and questionable appreciation of students levels and scores in various exams (national or regional) are equivalent to school achievement, criticizing schools that don't have resembling scores, and differences and variances about resources use, private high schools have higher levels of narcissistic characteristics than state high schools, state high schools for which teachers and students are selected via a national entrance and placement examination have higher levels of narcissistic characteristics than other state schools in which no such an exam is conducted.
\end{abstract}

Keywords: Organizational Narcissism, Narcissism, High School.

\footnotetext{
* Orcid ID: https://orcid.org/0000-0003-2833-2931, Assist. Prof. Dr., Sakarya University, Faculty of Education, Educational Administration and Management, mhamed@sakarya.edu.tr
} 


\section{INTRODUCTION}

Although organizations are structures generated by individuals, it is widely seen that they are generally attributed entity and power to control the founders and employees (Morgan, 1998: 241). In some cases, the effect of the organizations is so powerful that the employees start to do something that they wouldn't/couldn't do at another organization or at their previous organizations or they react differently. Working at certain organizations is seen as a privilege. As a matter of fact, being a part of some organizations even for a short time has precedence for the employees. People may utter sentences like "retired from ..." or "graduated from ... School/University" to give reference to some organizations.

Some organizations have associations which do not accept members from other organizations. There are some privileged jobs or positions which prefers employees from specified schools although one of the application requirements was "graduation from certain institutions". For instance, district governors are preferred among the graduates of Ankara University Faculty of Political Sciences (formerly known as mülkiye) even though it isn't written in the legal or administrative texts. Being a graduate of some universities such as Istanbul Technical University or Middle East Technical University is always a privilege when applying an engineering position. While medical schools of Hacettepe, Çapa or Cerrahpaşa Universities were among the first to remember, being or having been a student of Bilkent University has its own privilege. This privilege is also seen in some high schools and/or secondary and primary schools as well such as Darüşşafaka High School, Galatasaray High School, ODTÜ High School, and Ankara Science High School.

Such schools lay a different burden on the principals, employees and students compared to their equals and accordingly provide a different self-confidence, image and vision to them. Even attending such schools, teaching at those schools and being in interaction with these people is considered as an indication of superiority. It is witnessed that some principals choose their teacher(s) even though it is against the law. This self-confidence can be associated with the personality of the principal as well as their personal relationships and the power of the school.

This situation can be considered as "acceptable" considering the fact that schools in the same category do not have the same educational quality in Turkey. The main aim of this study is to emphasize the organizational reflection of a personality structure in human beings called narcissism instead of discussing whether some schools deserve this privilege or not. The organizational reflection of this condition which can be seen in some human beings is tried to be explained via narcissism metaphor.

After the detailed explanation of narcissism, the concept of organizational narcissism will be discussed as a group behavior displayed by a member of an organization similar to the narcissism seen in the human beings. 


\section{Narcissism}

The concept of narcissism was named after the story of Narcissus in mythology (Shapiro and Shapiro, 2006: 25). Narcissism is closely related to the feeling of self-love, feeling special and self-contentment. Narcissism is defined as the investment of libido into the self in psychiatry literature.

This definition expresses that the structures in the spirit are organized towards selflove. These spiritual structures affect the perception and evaluation of an individual of oneself, other people and the world. They are also crucial factors determining the conscious or unconscious expectations, objectives, targets and self-evaluation (Özmen, 2006).

One of the primitive examples of narcissism is seen in the attitude of an individual towards his/her own body. There is no aesthetic or another sort of judgement. Anything related to oneself feels pleasant (Fromm, 1982: 65).

The relationship between narcissism and psychopathology underlines the ignorance of the fact that normally developed and healthy narcissism is vital for a healthy adaptation (Masterson, 2006: 15). Narcissism is essential for high self-esteem level and fulfillment of the vital necessity of an individual. Therefore, each individual has narcissistic characteristics even if it is minimal. Narcissism is not a personality disorder; rather it is the libidinal complement to the egoism of the instinct of self-preservation and a characteristic that can be attributed to any living creatures (Freud, 2007: 23). Thus, the differences between normal narcissism and pathological narcissism should be realized (Özmen, 2006). Narcissism is beneficial for the psychological health related to high selfesteem (Sedikides et.al, 2004: 400).

Narcissist people need confirmation of their narcissism, being applauded and being praised by the other people and thus they try to take the responsibility of the hard tasks (Wallace and Baumeister, 2002: 819). They prefer quick applause and appreciation to the success in the long term (Buss and Chiodo, 1991: 179). The performance of an individual increases with his/her independence and power on the subject (Erçetin, 1995: 60). Although many people has negative thoughts towards narcissist people (Maccoby, 2002: 38), their narcissism is generally nurtured by the toady people around them especially if they are the leader of a group. After a while everything they say and everything they do would be regarded as correct. Therefore, they are always in need of a friend, especially a co-worker, who knows these narcissist leaders very well to act like their extension and sometimes like an anchor whenever necessary. Don Quixote who lost his connection with reality but at the same time who managed to escape numerous dangers thanks to his servant Sancho Panza is a good example for such a case (Maccoby, 2002: 51).

\section{Organizational Narcissism}

Individual narcissism was used as a simulation tool while generating the concept of organizational narcissism (Brown A. D., 1997: 650; Hatch and Schultz, 2002). Narcissism 
is about personality at individual level. Therefore, it would be useful to explain the concept of organizational personality to fully comprehend the organizational narcissism.

Although people tend to act according to their personality structures, sometimes they had to limit themselves to adapt to the society in which they are living. They develop personality characteristics helping them act like the way they had to do in order to adapt to the organizational conditions in accordance with the organizational targets and the expectations of the other members of the organization.

Different communities or classes in a society have unique personalities and different visions develop and gain strength based on these personalities. Organizational personality is a metaphor discussing and analyzing how the members of the organization perceive their organization, how they feel about their organization and what they think (Hatch and Schultz, 1997: 356).

It is stated that the not only the levels if narcissism but also the number of the narcissists people have increased over the years (Twenge et.al, 2008: 875; Lasch, 2006: 82; Roberts and Helson, 1997: 641; Twenge and Foster, 2008: 1619). In the literature the reasons of the narcissistic behaviors were listed as individualization in the capitalist societies and narcissism culture created by the competitive environment (Lasch, 2006; Fromm, 1999). Cultural narcissism occurs within the popular media and social criticisms is pathology of the today's society (Tyler, 2007: 343; Lasch, 2006: 297).

While narcissism tends to be lower in the traditional societies, it is rather high in societies like the United States of America where individualism and individual satisfaction are underlined in all cases (Tschanz, Morf and Turner, 1998).

Human beings see the life as a capital to be converted to income in the modern industrial society. The life of a person will become meaningful if this target can be achieved, otherwise he/she will be identified as "unskillful". His/her value is in his charm, in other words in the appearance. In short, the value of a human being is determined by external factors such as gained achievements or decisions of other people. As a result the individual becomes estranged not to himself and but also to the others and he became a robot (Fromm, 2004 b.: 14).

Modern industrial society popularizes the narcissist people, reveals and reinforces the narcissistic characteristics seen in every individual, prioritizes the narcissism in a charming way and above all creates a variety of addiction type (Lasch, 2006: 357).

Organizations consist of members moving around a common personality and the selfesteem of the organization is composed of the corporate self-esteem of the members acting on behalf of the organization (Brown A.D.,1997). Organizations are motivated by the protection of their corporate personality and legitimacy just like the human beings (Brown A.D., 1997: 683; Ganesh, 2003: 558; Fromm, 1999: 259). They create a belief system and culture helping their members understand who they are, what they should become and how they should behave within the limits of a personality in a corporate group (Whetten, 2006: 219). Member of an organization also becomes a part of the organizational culture which means "believe in what others believe and do what others 
do". If we want to figure out how the human energy is motivated and how it turns out productive power, our main focus should be on organizational personality (Fromm, 1999: 258).

Each organization can create a corporate self-esteem via ego-productive behaviors. Organizations can develop commonly shared opinions on their own identities, unique and distinctive choices, dependencies and practices and distinguishing defense mechanisms to cope with the uncertainties and to protect their personalities. They do this not only to protect its personality but also to enhance the legitimacy of the collective groups (Brown A. D., 1997: 650; Duchon and Drake, 2007: 2). The personality of an organization emerges and takes form as the adaptation and integration problems are solved and alternatives displaying basic and constant characteristics generating the personality are found (Schein, 1992: 4).

This narcissistic reaction is a coping mechanism targeting to protect the personality of the organization. Members of the organization are motivated to maintain the self-esteem reflecting their social categories and in which they also participate and organization rewards the members displaying this personality in the best possible way. Efforts to maintain the personality is essential for the continuity of the organization and it should be a must for the organizations (Schein, 1992: 4). Such reinforced behaviors and attitudes are imitated by the others and thus organizational narcissism institutionalizes in time (Brown A. D., 1997: 650). In this manner, narcissistic defense mechanisms like organizational denial and grandiose builds the personality of the organization and promotes the existence for self-acceptance. In the course of time organization becomes more interested in proving its own existence instead of serving for the benefit of public (Brown A. D., 1997: 644).

\section{Narcissist Organizational Behaviors}

The effect of business life on the human beings and their personality has been found out both in theoretical studies and in studies which aren't directly related to the topic. Experiences gained throughout the business life can play a central role in the values, attitudes and behaviors of the employees, can have an influence on their personalities and can form their personalities besides the organizational behavior (Aytaç, 2007).

The theory and concept of narcissism in the organizational studies can be used to comprehend both the personality of the group and organization and the dynamics lying under the behaviors of the members of the organization. Although the theory is applied at the level of the individuals, it is also convenient for analyzing the group dynamics and organizational behavior (Duchon and Burns, 2008: 354).

\section{Grandiose and Arrogance}

People with narcissistic personality accept only their good characteristics in their own perception and act as if they are "the gift of God for the Earth". They are the best in 
beauty, intelligence, authority etc. Most of their sentences start with "I" as they are in need of introducing themselves before introducing others. In fact, the others are there to admire them. Narcissistic people experience difficulties in displaying their sincere feelings like regret, sorrow or grief when they hurt other people or lose their friendship (Volkan, 2005: 26-267). Narcissists feel more confident in cognitive and motivational domains like intelligence, creativity and leadership (John and Robins, 1994s 206) and they are surer of themselves (Campbell, Goodie and Foster, 2004: 311) compared to the real life. Narcissistic people give the feeling of inaccessibility to the people they are related to. They put on an untouchableness shield. People should obey and exalt them (Saydam, 1996: 420).

Members of the narcissist organization also believe that their organization is unusually special and unique. This perception reflects exaggerated illusion instead of an ordinary proud and success. The illusion of the narcissist organization causes underestimation of the other organizations, people and information; thus, victory and contempt arise (Stein, 2003: 532). These attributes enable the organization to prove and legitimate the rumors of uniqueness which have a functional value in defining competitive site and displaying itself as an ideal actor in this site (i.e "this is what we are etc.). These underlie the necessary activities for the main policy, programs and procedures of the organization and provide these as reference points in decision making and communication (i.e "these are what we do etc.). This reference point is based on the fact that the organization has fulfilled the assumptions on the current environment and its position within this environment. When internal reference point requires adequate material, it partially or completely covers the external reference point which is broader (Duchon and Drake, 2007: 1).

\section{Omnipotence}

One of the senior executives in Oracle mentioned that "The only difference between Larry and God is that God doesn't believe that He is Larry" while describing the narcissist executive of the corporation. Even this mention clearly reveals the situation of the narcissist people especially when they are at the peak (Maccoby, 2002: 38).

There are many studies in the literature presenting the positive relationship between the high self-efficacy perception and high motivation towards taking action, making more effort in practicing these actions and showing more persistence to overcome the obstacles. This suggestion is supported with the meta-analytical study on the relationship between business performance and self-efficacy conducted by Stajkovic and Luthans (1998) and with the researches made by Paglis and Green, 2002 and Prussia, Anderson, and Manz, 1998 on the relationship between the self-efficacy and effective leadership (Anderson, Krajewski, Goffin and Jackson, 2008: 595-596).

When these findings are examined from the point of organizational behavior, it can be implied that organizations with high self-efficacy perception behave more effective and active compared to the ones with low self-efficacy perception. Contemporary 
organizations especially big corporations have become extremely powerful social entities and they considerably conceal the role of the governments in controlling and leading the lives of the citizens and affecting collective social development (Deetz, 1992: 54). Organizations act as if they are in a battle and they struggle for constant innovation and improvement when they are within a competition regarding winning or losing. This is a chronic crisis appropriate to the vision holder attitude of the narcissist people (Brown B., 2005: 83). Strong self-enhancement and sovereignty turn into a sort of exploitation and absolute power. Organization is the entire power and anything constituting the power belongs to it. Such organization cannot reorganize a value occurring apart from its own class (Stein, 2003: 532).

\section{Exhibitionism}

A self-image originating from their own exhibitionism and disdaining others is observed in the narcissist people (Bogart, Benotsch and Pavlovic, 2004: 35). Narcissist people display characteristics like featuring their own successes, talking about themselves all the time, associating the topic with their own successes while pretending to listen to other people.

In the modern society, where individuals who can do outstanding marketing appreciated instead of the ones who make real effort, organizations give a narcissistic reaction and frequently award this reaction. Organizations spend a considerable amount of their income to marketing and advertising most of which appeals to eye of the external stakeholder to project a positive image on like on-wall advertising. Thus, they feel powerful and special and they can gain more strength with the increasing demand. This is an expected reaction. However, at some points organizations can develop personality characteristics which accept waste as a usual attitude. Even waste can be regarded as an indicator of power. They tend to spend extreme amounts with reference to the saying "the more you spend, the more powerful you are." For instance, Enron developed an organizational characteristic with a sovereignty feeling accepting the waste as not only usual but also required. While this company made architecture investments which are worth a fortune, it is also a source of pride for them to announce that they spent 100 million dollars for the royalty of stadium of Houston Astros baseball team (Duchon and Burns, 2008: 361).

\section{Admiration}

Narcissist people are dependent on others to validate their own values (Lasch, 1984). The aim of the arrogant narcissist people is to be approved by the others in terms of capability and even failure (Jacoby, 1990). They are sensitive about any kind of criticism and they get either angry or upset denying the validity of it. Narcissism can be hidden via humbleness and modesty. A narcissist person frequently uses these features to make others admire him. Disconnection with the external world is the common characteristic 
for the all narcissistic types no matter what the various symptoms are (Fromm, 1982: 68).

Organizations need mirroring to establish a balanced personality which will grow and develop with the changing conditions and a changing people. If the members of the organization believe in themselves less or more positive than the others see, they are motivated to change either their personality or their appearance based on this difference. They think environmental reactions concerning the organization are considered as the mirror of the organization and attitudes of the organization take form according to the likes or dislikes of these reflections (Dutton and Dukerich, 1991: 551).

However, the members of the organization develop their personalities based on the perceptions of the others instead of the utterances of the others about them. Dutton and Dukerich give the example of Port Transportation Company. Members of Port accepted their image observed by the others besides they tried to change this image as well. They did so with the feeling occurred by the perceived images of the others (Dutton and Dukerich, 1991: 554).

\section{Leadership and Authority}

Although a narcissist can agree with the therapies assuring adding meaning to life and overcoming the feeling of emptiness, they display a considerable performance and gain success throughout their vocational career. He has an innate ability in managing the personal impressions and he is an expert in coping with such chaos; thus these qualifications serve well for the narcissist in the political and commercial organizations where "visibility", "dynamism" and a decent registry are more important than performance. As the "man of the organization" turns into a bureaucratic "man of game" and "age of loyalty" of the business life turns into the age of "administrative success game", the narcissist demonstrate himself by presenting his skills (Lasch, 2006: 84).

Organizations consistently strive to be more superior to the others and even themselves in various areas (Hatch and Schultz 2002: 132). They develop several visions both to make a display and to motivate the employees during this struggle. For instance, after a while the common vision of being a leader within their own category and being a model and source of inspiration might become an opinion shared by all the members whether it is real or not. Besides, organizations make use of such opinions to inspire the other organizations and manipulate the actions. They would think that they are the authority of their category and that they know the best because of some accomplishments. The organization can reach any information about itself both internally and externally as it believes in the fact that it knows everything. In time such features become so common that they also become a settled part of the organizational culture (Stein, 2003: 532). 


\section{Organizational Narcissism Types}

There are two types of organizational narcissism as it is in individual narcissism. While one of them is called "destructive organizational narcissism" which harms the organization (Duchon and Burns, 2008: 1), the other one is "productive narcissistic organization" which is in search of arranging the self-respect by managing the defense mechanisms to decrease the anxiety of the organization or its members seeking their rights and improving themselves (Brown A. D., 1997: 1).

\section{Productive Organizational Narcissism}

A person who is at peace with himself, who loves himself, who is pleased with himself also loves others without feeling any doubt, grudge or jealousy. This is possible when the person embraces his negative sides as well as his positive sides. Counting on one's selfesteem and thus ignoring any support on self-esteem are the essential features of narcissism (Özmen, 2006). Productive narcissism or positive self-evaluation refers to high self-confidence. This is characterized by having positive feelings about oneself, having self-confidence and self-sufficiency (Pulver, 1970: 319). At their study conducted with the undergraduate students Zeigler-Hill found out that high self-esteem is associated with the indicators of the psychological regulations and thus it is beneficial for the individuals (Zeigler-Hill, 2006: 119). Productive narcissism supports belonging, gratitude, balances pride, separation and superiority and tolerates guilt and loneliness (Ronnigstam, 2005: 43).

As it is valid for the humans, productive narcissism is regarded necessary among the members of the organizations in terms of self-respect and organizational respect in organizational perception and thus in the perceptions of the employees. In a similar manner, organizations like themselves and take some precautions to protect their existence which is also seen among the humans who like and protect themselves to survive. The term of productive narcissistic organization is used for the organizations which protect their identity via self-confidence. Such organizations reach success instead of believing that success is their right and use the data to get information and inform others instead of denying them (Duchon and Burns, 2008: 354).

Organizations take action corporately when they are motivated to protect their selfimages reflecting their social categories. They can capitalize on the narcissistic behaviors such as determination against the social pressure and ceaseless effort. It can be implied that self-confident organizations focused on the strength would be more efficient and would have a better chance for a quality living (Duchon and Burns, 2008: 643-644). Thus, the organization can manage its corporate self-esteem besides securing its legitimacy by protecting its identity via ego-productive behaviors (Brown A. D., 1997: 650).

Productive narcissism can improve the performance of organization. Accomplished and skilled narcissist organizations can carry out creative achievements by uniting their grandiose fantasies and self-investments (Maccoby, 2003; Ronningstam, 2005, p. 79). A 
smart and reflective organization emerges as a result of the skillful administration and reflection on the structure of the identity. Such an organization counts on its skill of making chances in its identity as a part of the prospective strategic developments (Brown and Starkey, 2000: 104).

\section{Destructive Organizational Narcissism}

Extreme narcissists are traditionally narcissist people. These people lack of feeling empathy towards others, are self-serving and are in competitive conflicts with others. Competitive conflict is a sort of conflict resolution in which participants perceive the improvement of others as an obstacle to their improvement. For instance, people who attach importance only to their own accomplishments, do not listening to others who take action laying a claim and who are socially aggressive are extremely destructive narcissist people (APA, 2000).

Extreme organizational narcissism can be harmful to the organizations and even destroy them. Extremely narcissist organizations lose their connection with the market and their clients while they are busy with themselves and their own anxieties. Being busy with itself becomes a daily routine and the organizations display reflections denying its own extremely narcissist identity (Duchon and Burns, 2008: 354).

Extremely organizational narcissism is a negative function of the identity (Hatch and Schultz, 1997: 356). Such organizations called egocentric organizations draw a line around the narrow definitions concerning themselves and they try to look out for themselves within this confined space. Sense of egocentric identity causes two negative consequences: sustaining the unrealistic identities and creating identities destroying the crucial constituents of the context in which it also takes place. Extreme narcissistic organizational identity displays oneself as eligible and legitimate at any cost (Brown A. D., 1997: 683). Organizations displaying extreme narcissistic characteristics lose the perception of reality related to their position within the system and have a vision of denial, self-exaggeration and grandiose, all of which destroy their identity.

An extremely narcissist organization is lack of empathy and has a sense of achievement coming with the need of exploiting others. They consider sustaining their success and exploiting the services of other organizations leading their members and sources to success as a skill. Such an vision is the indicator of different implications depending on the high or low self-esteem of the organization. In general, organization with a high selfesteem is characterized with exaggerated sense of self due to the high self-esteem and thus tends to ignore its weakness. A self-exploiting organization cannot sustain its reliability and its competitive characteristic becomes a disadvantage (Duchon and Burns, 2008: 355).

Extreme narcissist organizations develop obsessive identities due to feelings like egotism, strong sovereignty and rebellion against the ordinary. Such an identity is ethically defective and they do not have a tendency to be ethical (Duchon and Drake, 2007: 5). They use ego-productive mechanisms to maintain the integrity of its own 
identity. Believing in its morality is more important than facing the indecency of its behaviors for an extreme narcissist organization. They plead a corporate psychological defense (Ketola, 2006: 149). Therefore, they have official ethical programs although they do not use them. They pretend to be ethical as such a vision reinforces their narcissism and planning expensive official ethical programs is not a big deal for them considering the ego-strengthening benefits. Thus, hiring the most prestigious consultants, organizing splendid programs and publicizing these programs in the media are essential for the extreme narcissist and egoist organization. "Morality" would be on the surface and corporate actions would be open to keep up with their own agenda (Roberts J., 2001: 127).

\section{Narcissism in High Schools}

Considering the competitive culture and individualism, productive narcissism is regarded essential in the high schools due to higher self-esteem, ability, eagerness and readiness for competitiveness. However, extremeness in narcissism and thus losing touch with reality would harm both to the school and its environment.

A decent education and high academic achievement is regarded as some of the outcomes of spending a comfortable and qualified life. Nowadays, students do not gain appreciation form others if they are not successful and accordingly do not feel secure physically or mentally. This sense of insecurity increasingly affects the lives of the students and their families. In such a testing environment the student has to prove himself starting from the primary school via various tests and he is always in search of institutions, organizations and educators to complete his missing points. The rate of the students who get a decent result in the exams is seen as a reflection of this situation for the schools and the teachers. As the lists of the successful students are the proof of the school when you are looking for a new school, schools and teachers are in an endless competition for being the one whose students were accepted in the best schools. Since passing the university exam is a matter of life or death for the high school students in Turkey, the above-mentioned search is mostly seen among the high school students who know that they have to get a reasonable result in the university exam if they want to be successful.

Passing the exam and proving success is also valid for the teachers. Teachers are mostly form the middle class (Açlkalın, 2007: 11). Members of the middle class are scared of losing their current position, not being able to get what others already had, being unsuccessful and consequently identified as "unskillful" (Fromm, 2004 b.: 66). Teachers with such fears can naturally develop narcissistic defense mechanism.

Educators with similar skills are in an endless competition to get the limited positions, to be better than the other school/teacher(s) and being ready for the next exam. Improvement has a connection with self-confidence, energy and entrepreneurism for the teachers. Eager and young teachers prefer master degrees and take some exams to be able to teach at Anatolian and Science high schools. 
Same narcissistic characteristics are also observed among the private schools. Candidates with personal magnetism, i.e. ones who easily influence others, have a higher chance even if all the candidates have similar qualifications. In short, interpersonal relations management is the core of personal development.

It can be thought that teachers working in the public schools do not have such an anxiety as their positions are secured. However, due to some factors the competition is seen both in the public schools and private schools. The competition gets fierce as some narcissistic concerns such as having a priority, being rewarded because of their accomplishments, being appreciated and praised, feeling superiority over the other schools are involved.

The productive narcissistic reactions of the schools are beneficial in terms of increasing their self-esteem and competitiveness and thus maintain their lives. The factors related to the narcissist school such as its success, vision, teachers, students and parents act as a mirror of the school and by looking at this mirror the school's nurtures and protects its egoism. The school sees itself whenever it looks at his students, parents and staff. The school sees the success or failure of the students as its own success or failure and the reflection from the mirror depicts it as a winner or a loser. Considerable amount of narcissism is an advantage in a competitive environment (Lelord and Andre, 2005: 127).

The acceptable narcissistic reactions of the schools such as being a role model, being regarded as the most successful school and gaining recognition due to its accomplishments can be considered as reasonable as long as the teachers and the principals do not lose their sense of reality. Even they can develop positive attitudes towards their organizations, strengthen their weaknesses and notice their strengths. Besides, an increase in their mood and motivation especially if they are getting positive reactions from their environment can be observed and they can carry their goals a step further.

Feeling special, expecting respect, enjoying telling and hearing about their school even taking pleasure while looking at their school would enhance the working conditions and increase their job satisfaction. Therefore, it can be implied that productive narcissism has positive contributions to the schools.

The staff can feel threated due to successive failures, humiliation by the colleagues, not getting respect etc. and they can display some extreme narcissistic characteristics. The failure(s) of the school causes a decrease in the demand, which means a decrease in the number of the students, and thus protective mechanisms emerge. Such a decrease is perceived as a threat both by the public school and especially by the private schools since private schools lose their students besides their reputation, positive reactions and priority.

If the school is extremely narcissistic, it can exhibit behaviors such as exaggerating its achievements which are not realistic, pretending that it is successful, denying the failures after the inspection and distracting others by ignoring the situation. Gorgeous 
graduation or opening ceremonies, investing in luxurious expenses instead of the real needs of the school are indicators of this situation.

The classification of the high school, being a public or private high school and acceptance procedures of their students, with or without an exam, are used as the variables determining the narcissism level of the high school in this study. For this purpose, answers of the following questions are sought throughout the study.

\section{Problem Statement}

What is the level of organizational narcissism in the high schools located in the central districts of Sakarya province? Is there are significant correlation between the organizational narcissism and the fact that the school is a public school or a private school, that the school accepts students after an exam or not.

\section{Sub Problems}

1. What is the organizational narcissism level in the private and public high schools located in the central districts of Sakarya province?

2. What is the organizational narcissism level in the high schools accepting their students after an exam and without an exam located in the central districts of Sakarya province?

\section{Significance of the Study}

The main of aim of this study is to raise awareness on the principals and teachers working at these schools on the positive and negative consequences of narcissism by making them think about the harmful outcomes of organizational narcissism such as grandiosity, arrogance, jealousy and exploitation. On the other hand, they can facilitate the productive narcissist characteristics in increasing their accomplishments. Besides, they can realize the significance of the psychological factors in coping with the positive and negative aspects of the schools.

\section{Limitations}

This study is limited to the general high schools, Anatolian high schools and Science high schools located in the central districts of Sakarya province in Turkey.

\section{METHOD}

\section{Model of the Study}

This study is designed in a survey model. It reveals the organizational narcissism levels of high schools based on their classifications and election method of their students. 


\section{Universe}

The universe of the study consists of both public and private general high schools, Anatolian high schools and Science high schools located in the central districts of Sakarya province in Turkey. If there are both Anatolian and Science high school within the body of the private schools, only one of them is included in the universe by drawing of lots. 18 high schools out of 21 identified this way generated the universe of the study.

\section{Sample}

This study is conducted with 54 principals and 502 teachers. As the number of the principals is considered insufficient, they aren't included in the sample. It was predicted that scales that can be filled incorrectly or deficiently and/or that won't be delivered might affect the validity of the sufficient scale number.

While determining the sample for the teacher's microcosm mean formula (Karasar, 2009: 123) was used and the sample for the teachers was found out as 237.

Considering the involuntary participants and the scales that wouldn't be delivered 260 teachers and 54 principals were included in the study. The proportion of the sample number to the universe revealed the number and school of the teachers.

When the undelivered and incorrectly or deficiently filled scales are eliminated, applicable data collected from 299 participants, 253 of who are teachers and 46 of who are principals are used in the study.

\section{Data Collection}

The researcher collected the data via assessment instrument developed by the researcher. The assessment instrument has two sections. In the first section questions about the status of the school - whether it is a private or public school - and the type of the school - whether it is a general high school, Anatolian high school or Science high school are asked. The second section consists of "organizational narcissism scale" to find out the organizational narcissism level.

\section{Organizational Narcissism Scale}

There is no scale in the literature measuring the organizational narcissism. Analysis of organizational narcissism is in accordance with the tradition of psychoanalysis (Brown A. D., 1997: 644). Therefore, items of the individual narcissism scale developed by Raskin and Terry which has 40 items (Raskin and Terry, 1988) were used to develop the organizational narcissism scale. The first version of the scale had 47 items. Expert opinions were taken to add and take out the items and the final version had 39 items after the necessary changes. 
The answers in the scale were scored according to 5 point likert scale in which 1 is used for "strongly disagree", 2 is used for "disagree", 3 is used for "neural", 4 is used for "agree" and 5 is used for "strongly agree".

According to the results obtained from the pre-practice 3 items with low factor load were taken out and the scale was divided into five factors. When the questions were analyzed, the sub dimensions were identified as grandiose and arrogance, leadership and authority, recognition and honoring, perception of omnipotence and exhibitionist behavior. Thus, an organizational narcissism scale with 36 items was developed. The $\alpha$ coefficients of the sub dimensions and the overall are listed below.

$\begin{array}{ll}\text { Dimensions } & \alpha \text { Coefficient } \\ \text { Grandiose and Arrogance } & : 0,90 \\ \text { Leadership and Authority } & : 0,80 \\ \text { Recognition and Honoring } & : 0,77 \\ \text { Perception of Omnipotence } & : 0,86 \\ \text { Exhibitionist Behavior } & : 0,86 \\ \text { Overall } & : 0,96\end{array}$

Looking at the alpha coefficients of the scales the reliability coefficients were seen as acceptable and high (Yurdugül: 7).

\section{Analysis and Interpretation of the Data}

The sub problem sequence was followed for the interpretation of the data. To determine the first sub problem of "narcissism levels based on / according to the five sub dimensions and the overall narcissism" separate and total scores were divided by the number of the question, mean scores related to each sub dimension and overall narcissism were calculated and it was rearranged according to the 5 likert scale. The mean scores gave the narcissism levels via the range calculated for the four ranges in the

5 likert scale as $(5-1=4)$ and $(4 / 5=0.80)$. Later on, mean $(\bar{X})$ was calculated to find out the central tendencies regarding the narcissistic behaviors and standard deviations were calculated to determine the dispersion in the universe. Besides, relative variation

coefficients $\left[\mathrm{V}=\left(\mathrm{ss}^{\prime} / \bar{X}\right) * 100\right]$ including the mean/ average, more informative (Baykul, 1999: 129) and stated as the percentage of the mean value of the related serial (Ağaoğlu, 2006: 63, Alpar, 2001: 48) were calculated to remove the drawbacks arising due to differences among the measurement units in the comparisons and the size of the observation values. Mean and standard deviations and relative variation coefficients were analyzed in the comparisons related to the consensus and it was interpreted that 
while a higher consensus was observed for the groups with lower standard deviation values and relative variation coefficients, a lower consensus was seen for groups with higher values.

These interpretations were made considering the thought that while medium narcissism is productive for the organizations, just like it is acceptable for the humans, "too high" or "too low" levels are destructive.

\section{FINDINGS}

\section{Narcissism Levels of Private and Public High Schools}

Table 1.

Narcissism Levels of Private and Public High Schools

High Schools

Private Public

\begin{tabular}{lcccccc} 
Dimensions & $\bar{X}$ & s.d. & V\% & $\bar{X}$ & s.d. & V \\
\hline Grandiose and Arrogance & 3,50 & 0,85 & 24,29 & 3,15 & 1,09 & 34,60 \\
Recognition and Honoring & 3,95 & 0,83 & 21,01 & 3,45 & 1,11 & 32,17 \\
Exhibitionism & 3,01 & 0,96 & 31,89 & 2,60 & 0,95 & 36,54 \\
Omnipotence & 3,84 & 0,83 & 21,61 & 3,13 & 1,14 & 36,42 \\
Leadership and Authority & 3,23 & 0,94 & 29,10 & 2,76 & 1,10 & 39,86 \\
General & 3,45 & 0,83 & 24,06 & 3,03 & 0,97 & 32,01
\end{tabular}

According to Table 4, the narcissistic perceptions of the principals and teachers working for private high schools on the recognition and honoring $(\bar{X}=3,95)$, omnipotence $(\bar{X}$ $=3,84)$ grandiose and arrogance $(\bar{X}=3,50)$ dimensions are between 3,41 and 4,20, therefore considered as "high". The same values are "medium" as the range is between 2,61 and 3,40 for leadership and authority $(\bar{X}=3,23)$ and exhibitionism $(\bar{X}=3,01)$ dimensions. The general organizational narcissism levels of the private high schools are high with $\bar{X}=3,45$.

While the narcissistic perceptions of the principals and teachers working for public high schools on the recognition and honoring dimension was "high" with $(\bar{X}=3,45)$, it was "medium" for the other dimensions and for the general as the narcissistic perception was between the range of 2,61 and 3,40. 
The standard deviation values and the relative variation coefficients (V) displayed a higher consensus on the narcissistic perceptions of the principals and teachers working for private high schools for all dimensions and for the general compared to the principals and teachers working for public high schools.

The "higher" narcissistic perception levels for the recognition and honoring dimension both for the private and public high schools is thought to be related to the criticisms on the quality of education in Sakarya in in recent years (Serhaber, 2009).

\section{Organizational Narcissism Level for the High Schools Accepting Students with or without an Exam}

Table 2.

Narcissism in the High Schools Accepting Students with or without an Exam

\begin{tabular}{lcccccc}
\hline & \multicolumn{7}{c}{ Acceptance Type } \\
& \multicolumn{3}{c}{ Without an Exam } & \multicolumn{3}{c}{ With an Exam } \\
Dimensions & $\bar{X}$ & s.d. & V\% & $\bar{X}$ & s.d. & V \\
\hline Grandiose and Arrogance & 2,63 & 1,03 & 39,16 & 3,54 & 0,91 & 25,71 \\
Recognition and Honoring & 3,12 & 1,19 & 38,14 & 3,8 & 0,92 & 24,21 \\
Exhibitionism & 2,2 & 0,97 & 44,09 & 2,95 & 0,86 & 29,15 \\
Omnipotence & 2,77 & 1,2 & 43,32 & 3,57 & 0,97 & 27,17 \\
Leadership and Authority & 2,31 & 0,99 & 42,86 & 3,16 & 1,02 & 32,28 \\
General & 2,58 & 0,95 & 36,82 & 3,41 & 0,83 & 24,34 \\
\hline
\end{tabular}

According to the table the narcissistic perceptions of the principals and teachers working for high schools accepting their students without an exam on the recognition and honoring $(\bar{X}=3,12)$, omnipotence $(\bar{X}=2,77)$, grandiose and arrogance $(\bar{X}=2,63)$ dimensions are between 2,61 and 3,40, therefore considered as "medium". The same values are "low" as the range is between 2,61 and 3,40 for leadership and authority ( $\bar{X}$ $=2,31)$ and exhibitionism $(\bar{X}=2,20)$ dimensions.

The narcissistic perceptions of the principals and teachers working for high schools accepting their students with an exam on the recognition and honoring $(\bar{X}=3,80)$, omnipotence $(\bar{X}=3,57)$, grandiose and arrogance $(\bar{X}=3,54)$ dimensions are between 
2,61 and 3,40, therefore considered as "medium". On the other hand, the general organizational narcissism levels of these schools are found as "high" $(\bar{X}=3,41)$.

The standard deviation values and the relative variation coefficients displayed a higher consensus on the narcissistic perceptions of the high schools accepting their students with an exam for all dimensions and for the general compared to the ones accepting their students without an exam.

The prominence of recognition and honoring dimension both in the private and public high school classification and the acceptance preference of the school classification underlines the fact that all of the high schools in Sakarya province experience an insufficiency related to this dimension.

\section{RESULT, DISCUSSIONS AND SUGGESTIONS}

It was found out that while private high schools present more narcissistic characteristics compared to the public high schools, Anatolian and science high schools have more narcissistic characteristics compared to the general high schools. Approval, appreciation and praise are among the expectations for the high schools just like the human beings. Employees would be more motivated and satisfied in such an environment. A desire for displaying, announcing and boasting about their achievements is common and natural. Features such as a pleasant and well-prepared working environment, convenient and appropriate materials are crucial for the interest and demand of a high school. Then, they can more easily focus on the success and become more eager and determined to fulfill their objectives as they feel more powerful. Private high schools are more advantageous in providing such environments.

There is a connection between the selection of the principals, teachers and/or the students and the organizational narcissism. High schools which can choose their principals, teachers and/or the students display higher narcissistic characteristics. These selection criteria can be either the academic achievements or the socio-economic status of the students or the teachers.

Opinions on the organizational narcissistic perceptions are highly common in the high schools where principals, teachers and/or the students are chosen. Organizational perceptions can be adopted by the principals and teachers in less than two years.

Although expectation of appreciation and approval is the highest narcissistic feature for all types of high schools, they are higher in the private schools compared to the public schools and in the high schools accepting students with an exam compared to the ones that do not require an exam result. While the high schools in Sakarya province aren't appreciated and approved as much as they expect, it is thought that such expectation for the private schools and the ones choosing their students after an exam result is connected to the low exam achievement rates of Sakarya province. These schools which are considered as more successful compared to the other high schools can speculate that 
they do not get the appreciation and approval they desired and that their efforts are wasted when they are announced as completely unsuccessful. Such speculation can be related to the sustainability of the educational activities despite the scarce sources and academically weak students.

As private high schools and the schools who accept students with an exam result can choose their teachers and students, it is known that they have numerous opportunities compared to the general high schools. Therefore, higher narcissistic perceptions on the grandiose and arrogance, omnipotence and leadership and authority dimensions are expected. Considering the student profile of such schools, it can be easily predicted that they belong to a higher socio-economic class by looking at the annual fees of the private schools and the budget required for the preparation for the exam.

Exhibitionist behavior is higher in the private high schools compared to the public high schools and in schools accepting their students after an exam compared to the ones that do not. The fact that narcissistic perceptions related to the exhibitionism have the lowest level compared to the other dimensions can be explained with the social structure in Turkey. As Sakarya province is known to have a traditional social structure, exhibitionist behaviors are generally disdained and scorned. However, such an attitude might be regarded as a necessity for the private high schools to attract the students and parents who are actually their life source.

While the exaggeration of the narcissistic characteristics can pose a risk for the high schools, their insufficiency is not preferred. Therefore, schools should be careful about this limit whether they accept their students with or without an exam.

The high narcissistic characteristics seen in the private high schools and schools which choose their students display that competitive culture is one of the most important components of organizational narcissism. Too many opportunities provide an advantage to the private schools over the public schools. A similar advantage is valid for the Anatolian or science high schools which have a chance to choose its students as well. Since preferred schools feed their ego because of the support from the other institutions and their environment, general high schools have a reverse situation.

The permanency of the competitive system can trigger and stimulate the excessive and undesired narcissistic characteristics of these schools. The high level of the grandiose and arrogant behaviors among the students attending private schools and ones that can choose their students is a demonstration of the above-mentioned fact. This can cause defense mechanisms such as denial, rationalization or ignorance in case of losing touch with reality or after a failure. The schools should be careful about wasting their sources on excessive advertisements such as gorgeous graduations.

In a system where the students are evaluated only with their success in the exams, the survival chance of the general high schools is very scarce compared to the private high schools, Anatolian and science high schools in terms of human resources like teaching staff and chosen students. These schools are also very disadvantageous in feeling special 
and omnipotent, seeing themselves as leaders and authority, expecting recognition and approval after displaying their achievements beside the private high schools and the ones accepting student with an exam as they are very busy with different issues like insufficient teaching materials or the discipline among the students. Therefore, lower self-esteem, feeling weak, giving up hope in success and a decrease in the job satisfactions are among the expected results.

The success rate in the exams is considered as the main indicator of the educational success in Sakarya, as it is common for the other cities in Turkey. This consideration is visible in the objectives of the administrators set throughout the projects developed to increase the educational success. For instance, the objective of placing Sakarya in the first 30 in 2010, the first 25 in 2011 and the first 20 in 2012 for the national exams like SBS, YGS and LYS are seen in the Project of Elevating the Success of Sakarya (Serhaber, 2009).

Above mentioned facts are also mean ignorance of the location of Sakarya which is an industrial city which is known for its numerous factories between the capital city of Ankara and the most crowded city Istanbul. Therefore, supporting vocational education and directing the talented students to vocational schools is crucial for Sakarya province. Such a motivation would decrease the demand to the general high schools and thus the quality of the education would be enhanced. Consequently, these schools would gain a higher self-esteem and prestige in the society.

\section{References}

Açıkalın, A. (2007). Ete Kemiğe Büründük Müdür Diye Göründük. A. Açıkalın, M. Şişman, ve S. Turan içinde, Bir Insan Olarak Okul Müdürü (s. 17-33). Ankara: Pegem A Yayıncilık.

Ağaoğlu, E. (2006). Merkezi Eğilim ve Değişkenlik Ölçüleri. (s. 35-66). Editör: A. F. Yüzer, İstatistik içinde. Esikişehir: Anadolu Üniversitesi Yayınları.

Alpar, R. (2001). Spor Bilimlerinde Uygulamalı İstatistik. Ankara: Nobel Yayın Dağıtım.

Anderson, D. W., Krajewski, H. T., Goffin, R. D., \& Jackson, D. N. (2008). Leadership SelfEfficacy Taxonomy and It's Relation to Effective Leadership. The Leadership Quarterly (19), 595-608.

APA. (2000). Diagnostic and Statistical Manual of Mental Disorders Text Revision (DSM$I V$-TR) (4. b.). Washington, DC: American Psychiatric Association.

Aytaç, S. (2007, Eylül 30). Örgütsel Davranış Açısından Kişiliğin Önemi. Aralık 12, 2009 tarihinde www.pdr.forum.net: http://www.pdrforum.net/index.php?topic=1600.0 adresinden alındı

Baykul, Y. (1999). İstatistik Metodlar ve Uygulamalar. Ankara: Anı Yayıncılık. 
Bogart, L. M., Benotsch, E. G., \& Pavlovic, J. D. (2004). Feeling Superior but Threatened: The Relation of Narcissism to Social Comperison. Basic and Applied Social Psychology (26:1), 35-44.

Brown, A. D. (1997). Narcissism, Identity, and Legitimacy. The Academy of Management Review , 22, 643-686.

Brown, A. D., \& Starkey, K. (2000). Organizational Identity and Learning: A Psychodynamic Perspective. Academy of Management (25), 102-120.

Brown, B. (2005). Narcissistic Leaders: Effectiveness and the Role of Followers. Otago Management Graduate Review , (3), 69-87.

Buss, D. M., \& Chiodo, L. M. (1991). Narcissistic Acts In Everyday Life. Journal of Personality , (59), 179-215.

Campbell, W. K., Goodie, A., \& Foster, J. D. (2004). Narcissism, Confidence, and Risk Attitude. Journal of Behavioral Decision Making, (17), 297-311.

Chen, P. Y., \& Popovich, P. M. (2002). Correlation: Parametric and Nonparametric Measures. Thousand Oaks California: Sage Publications.

Deetz, S. (1992). Democracy in an Age of Corporate Colonization: Developments in Communication and the Politics of Everyday Life. New York: Suny Press.

Duchon, D., \& Burns, M. (2008). Organizational Narcissism. Organizational Dynamics, (37), 354-364.

Duchon, D., \& Drake, B. (2007, February 2007). Organizational Narcissism and Virtuous Behavior. October 12, 2008 tarihinde http://www.springerlink.com/content/8755t52711q62464/ adresinden alındı

Dutton, J., \& Dukerich, J. (1991). "Keeping an eye on the mirror: Image and Identity in Organizational Adaptation”. Academy of Management Journal, (34), 517-554.

Erçetin, Ş. Ş. (1995). Ast Üst İlişkileri. Ankara: Şafak Matbaacılık Ltd. Şti.

Freud, S. (2007). Narsizm Üzerine ve Schreber Vakası. (B. Büyükkal, ve S. M. Tura, Çev.) İstanbul: Metis Yayınları.

Fromm, E. (2004 b.). Çağdaş Toplumların Geleceği. (A. Arıtan, ve K. H. Ökten, Çev.) İstanbul: Arıtan Yayınları.

Fromm, E. (1999). Özgürlükten Kaçış. (S. Budak, Çev.) Ankara: Öteki Yayınları.

Fromm, E. (1982). Sevginin ve Şiddetin Kaynă̆ı. (Y. Salman, ve N. İçren, Çev.) İstanbul: Payel Yayınevi.

Fromm, E. (2004 a.). Toplumsal Bilinçaltının Araştırılması. (A. Arıtan, Çev.) İstanbul: Aritan yayınları.

Hatch, M. J., \& Schultz, M. (1997). Relations between Organizational Culture, Identity and Image. European Journal of Marketing (31), 356-365. 
Hatch, M. J., \& Schultz, M. (2002). The dynamics of organizational identity. Human Relations, (8),115-139.

Jacoby, M. (1990). Individuation and narcissism: The Psychology of The Self in Jung and Kohut. London: Routledge.

John, O. P., \& Robins, R. (1994). Accuracy and Bias in Self-Perception: Individual Differences in Self-Enhancement and The Role of Narcissism. Journal of Personality and Social Psychology, , (66), 206-219.

Karasar, N. (2009). Bilimsel Araștırma Yönetemleri (19. Baskı b.). Ankara: Nobel Yayın Dağıtım Tic. Ltd. Şti.

Ketola, T. (2006). Corporate Psychological Defences:An Oil Spill Case. Journal of Business Ethics , (65),149-161.

Lasch, C. (2006). (S. Öztürk, ve H. Yolsal, Çev.) İstanbul: Bilim ve Sanat Yayınları.

Lelord, F., \& Andre, C. (2005). Zor Kişiliklerle Yaşamak. (R. Madenci, Çev.) İstanbul: İletişim Yayınları.

Maccoby, M. (2002, Şubat). Narsist Liderler. Lideri Lider Yapan Nedir? , 35-60. (MESS, Çev., ve M. S. Sendikası, Derleyici) İstanbul: Harvard Business Review.

Maccoby, M. (2003). The Productive Narcissist: The Promise an Peril of Visiomary Leadership. New York: Broadway Books.

Masterson, J. F. (2006). Narsisistik ve Borderline Kişilik Bozuklukları. (B. Açıl, Çev.) İstanbul: Litera Yayıncllık.

Morgan, G. (1998). Yönetim ve Örgüt Teorilerinde Metafor. (Z. Dicleli, Çev.) İstanbul: Metal Sanayicileri Sendikası.

Özmen, E. (2006). Kendini Tanıma Rehberi. İstanbul: Sistem Yayıncılık.

Öztürk, O. (1997). Ruh Sağlığı ve Davranış Bozuklukları. Ankara: Hekimler Yayın Birliği.

Pulver, S. (1970). Narcissism-The Term and the Concept. Journal of American Psychoanalictic Assocation (18), 319-341.

Raskin, R., \& Terry, H. (1988). A Principal-Components Analysis of the Narcissistic Personality. Journal of Personality and Social Psychology Inventory and Further Evidence of Its Construct Validity , (54), 890-902.

Roberts, B. W., \& Helson, R. (1997). Changes in Culture, Changes in Personality: The Influence of Individualism in a Longitudinal Study of Women. Journal of Personality and Social Psychology (72, No. 3, ), 641-651.

Roberts, J. (2001). Corporate Governance and the Ethics of Narcissus. Business Ethics Quarterly, (11), 109-127.

Ronnigstam, E. (2005). Identifying and Understanding The Narcissistic Personality. New York: Oxford University Press. 
Saydam, B. (1996). Narsisistik Kişilik Bozukluğu, Antisosyal Kişilik Bozukluğu, Borderline Kişilik Bozukluğu: Psikodinamik Açıdan Benzerlikler, Farklılıklar. Ege Psikiyatri Sürekli Yayınları, (3), 413-430.

Schein, E. H. (1992). Organizational Culture and Leadership (2. b.). San Francisco: JosseyBass.

Sedikides, C., \& Diğerleri. (2004). Are Normal Narcissists Psychologically Healthy?: SelfEsteem Matters. Journal of Personality and Social Psychology, (87), 400-416.

Serhaber. (2009, Ekim 18). Sakarya'da Eğitim Masaya Yatırıldı. Kasım 1, 2009 tarihinde Serhaber: http://www.serhaber.com/-27235-sakaryada-egitim-masaya-yatirildi.jsp adresinden alındı

Shapiro, J. L., \& Shapiro, S. B. (2006). Mental Disordesrs of the New Millenium (Cilt 1). Greenwood, South Carolina: Praeger Publishers.

Stein, M. (2003). Unbounded irrationality: Risk and Organizational Narcissism at Long Term Capital Management. Human Relations, (56), 523-540.

Tschanz, B. T., Morf, C. C., \& Turner, C. W. (1998). Gender Differences in the Structure of Narcissism: A Multi-Sample Analysis of the Narcissistic Personality Inventory. Sex Roles, (38), 863-870.

Twenge, J. M., \& Foster, J. D. (2008). Mapping the Scale of The Narcissism Epidemic: Increases in Narcissism 2002-2007 Within Ethnic Groups. Journal of Research in Personality (42), 1619-1622.

Twenge, J. M., \& Diğerleri. (2008). Egos Inflating Over Time: A Cross-Temporal MetaAnalysis of the Narcissistic Personality Inventory. Journal of Personality (76:4), 875902.

Tyler, I. (2007). From 'The Me Decade' to 'The Me Millennium': The Cultural History of Narcissism. International Journal of Cultural Studies, (10), 343-363.

Volkan, V. (2005). Körü Körüne İnanç. İstanbul: Okuyan Us Yayınları.

Wallace, H. M., \& Baumeister, R. F. (2002). The Performance of Narcissists Rises and Falls with Perceived Opportunity for Glory. Journal of Personality and Social Psychology, (82),819-834.

Yiannis, G. (2005). MBA and the Education of Leaders: The New Playing Fields of Eton? Leadership (1), 147-163.

Yurdugül, H. (tarih yok). Ölçme Kuramı ve Güvenirlik Katsayıları. Retrieved from http://yunus.hacettepe.edu.tr/ yurdugul/3/indir/Guvenirlik.pdf on 10.10.2018.

Zeigler-Hill, V. (2006). Discrepancies Between Implicit and Explicit Self-Esteem: Implications for Narcissism and Self-Esteem Instability. Journal of Personality, 74(1), 119-144 